\title{
HUMILIATION, JUSTICE AND THE PLAY OF ANXIETY IN COMPETING
}

JURISDICTIONS.

\section{JULIET B ROGERS}

School of Social and Political Sciences

University of Melbourne

Australia

Tel: +61 390157945

Email: julietr@unimelb.edu.au

ABSTRACT. In colonial nations, such as the land called Australia, the two registers of settler and Indigenous jurisdictions compete at the level of symbolic certainty. In Lacanian psychoanalytic theory neither can arrive at perfect symbolisation but the struggle and the proximity to their arrival can evoke anxiety. What insists to keep this anxiety at bay, in non-Indigenous Australia, is what Jacques Derrida calls justice. As an impossible object, similar to the Lacanian object petit $a$, justice must be interminably animated to hold this object of desire in play. Humiliation of Indigenous people in Australia is, I argue in this article, one mode of this play. I interrogate the psychoanalytic discussions of anxiety by Freud and Lacan to consider firstly what might be the cause of anxiety for contemporary non-Indigenous Australians and secondly how this anxiety is 'played out' on the bodies of Indigenous people through practices of humiliation. As one example of this work of humiliation I consider several scenes of police practice in the Sydney suburb of 'Redfern' from the 1991 documentary Cop It Sweet. 
KEYWORDS. Anxiety, Australia, Cop it sweet, humiliation, jurisdiction, psychoanalysis.

The point where the different systems of justice become entangled, does the need to enforce the law appear to become paramount. (Muldoon 2008, p. 69)

One always struggles to write on anxiety, particularly one's own, and perhaps particularly as a non-Indigenous Australian. Even the careful work of Dylan Evans on the psychoanalytic concept of anxiety is fraught with an unusual simplicity. The reasons for this, one can only imagine, are because writing on anxiety makes you anxious. In the face of anxiety one clings to an object, often defined as such through law, or some other discourse that pertains to master reality. Evans' cling is helpful for us to understand the clingy-ness of non-Indigenous Australians to the object of/as law in what Tim Rowse calls 'the ongoing colonial encounter we call "Australia"' (1993, p. 129), precisely because, in Evan's terms, anxiety seems only able to be understood as a binary choice between the ideas of Freud or Lacan. For Freud, in Evans' terms, anxiety is caused by separation from the Mother; for Lacan it is caused by the proximity of return. As if one is left with a choice of fathers to agree with, or indeed to go to. However, as Domeniek Hoens notes, the text of Lacan's Seminar XI is precisely on 'the dialectic of distance and proximity' (2016, p. 105); that is, it is the texture, or, (if I can add another master) in Donald Winnicott's more simple terms, it is in the experience of the distance that anxiety insists (1971). In this depiction, anxiety is not a question about being too close to or too far from the mother; it is what appears in the relation to that relation - including its loss and its imagined reacquisition - which allows one to wrangle with the absence of it and the impossibility 
of its return. This is the same relation which one has to the object petit $a$, so crucial to our understanding of anxiety and law, as I will show.

The unusual, what we might call, phallocentric foolishness, on the part of Evans indicates something precisely of the pressing pains of anxiety in Australian jurisdictional uncertainty. This is because it is the texture of the separation that allows us to think of anxiety. That is, the relation is what is put in place of the separation, not an object per se but an imaginative frame, or what Jaco Barnard-Naudé discusses (in this edition) as the support for the lack, that allows us to ensure the lack is bearable. Evans, however, in this demand to choose between the discourses of two masters, shows us something of the legal anxiety of Australia. Between the jurisdictions that are Indigenous and British (and later Australian) law, what I suggest is put in place is a relation of acquisition; a relation that attempts to grasp and then to play with the fleeting object that are Indigenous bodies who might obey otherwise. This play is a kind of diversion, as I will explain, from the object $a$, which is, as Lacan discusses in Seminar $X$, reiterated in Hoens' terms here as 'the object of anxiety, which occurs when lack is lacking, or, put differently, when the subject gets too close to what causes its desire.' (2016, p. 105). In Evan's categorisation of Lacan's terms - also reiterated interminably by Slavoj Zizek - it is the return to the mother's womb which is the cause of anxiety; the possibility of that return is to have all desire consumed, or devoured in Renata Salecl's idiom (2004, p. 24). ${ }^{1}$ What I will focus on here is a concern with proximity and how the subject, specifically the subject affiliated with law as police and judges, manages the proximity with what causes its desire.

\footnotetext{
${ }^{1}$ This is a different configuration from the confrontation with the mother's womb which, in Slavoj Zizek, brings us back in contact with the Real (2006).
} 
In this article I interrogate the psychoanalytic discussions of anxiety by Freud and Lacan to consider firstly what might be the cause of anxiety for contemporary non-Indigenous Australians and secondly how this anxiety is 'played out' on the bodies of Indigenous people through practices of humiliation. The ordinary claim about the anxiety for non-Indigenous Australians is about the morality of their claims in the present, given the history of treatment toward Indigenous people (Muldoon 2003, p. 183). ${ }^{2}$ I suggest, using Freud, that the morality argument - as compelling as it is - covers a more disturbing possibility: that non-Indigenous people, and police particularly, need to play, toy with, or humiliate Indigenous inhabitants, in an effort to enjoy their animation beyond the biological production of 'the indigenous race'; that non-Indigenous legal officials ${ }^{3}$ feel a pathological anxiety about the political resurrection of Indigenous nations in the space of an uncertain jurisdiction, called Australia. This anxiety, I suggest, is managed through the arrangement of Indigenous bodies before law. That is, I will argue here, practices of law become practices of what have been described by legal officials in another context as 'creative punishment ${ }^{34}$ in a mode that is less about the dehumanising of others, as writers on violence tend to suggest, and more about the production of others as lively objects; very much alive and importantly so for the purposes of reinforcing an uncertain jurisdiction, and mastering the anxiety of illegitimate authority in a colonial context.

\section{PART I - LAW, SPEECH AND PLAY}

\footnotetext{
${ }^{2}$ This is also referenced as non-Indigenous 'guilt' (Gaita 1998) or 'unease' Biber (2002).

${ }^{3}$ This is readily extended to those that affiliate with legal officials and seek security in jurisdictional certainty in other forms, but I am expressly dealing with officials in this work.

${ }^{4}$ I am referencing comments by Israeli border guards, as discussed in other work: see Rogers (2016).
} 
Anxiety is expressed in the activity of dodging, let us call it, the Real. Or, in a more simple reading, it is in the effort to name, to symbolise, or in legal terms, to categorise 'reality' before one comes into contact with the Real. The effort to categorise, to name, to offer support for the lack is an ordinary affair, in most circumstances. It is the work of speech, which always endeavours to claim the correct referent; an impossible task, but one well worth the effort if you want to exercise desire and work towards its satiation, (again, in psychoanalysis, the achievement of which is an impossible task). The work of speech to claim the referent is our object of analysis here, because it is also the work of law.

There is little to distinguish the moment that Freud described of the game played by his grandson with the cotton reel, the game known as 'fort' 'da' from the efforts of law (2001). Fort da is the game where the child would throw the reel (or bobbin, in Lacan's terms) from its cot and exclaim 'fort' (gone, in German) only to pull it back and exclaim 'da' (here) as if it could name the event and thus have some sway over the reality that had befallen it and indeed him. The reality he was attempting to manage (and here is where we see Freud's emphasis more clearly) was the absence of the mother, and hence this game is about loss and, from a child's perspective, a game that relieves him of the anxiety of his mother's indefinite (non)return. But Lacan would put a different emphasis that is more helpful when thinking about law. For Lacan:

This reel is not the mother reduced to a little ball by some magical game...it is a small part of the subject that detaches itself from him while still remaining his, still retained. (1977, p. 61)

What is still retained is a piece of the self that comes to stand, not for the mother herself, but for the piece of the self experienced as cut off, as removed, as, of course, castrated from the little child. That is, the mother's absence introduces, for the child, 
the experience of himself as not able to be master of his world entirely, and in psychoanalysis the simple word for this experience is 'castration' (Lacan 1977, p. 64). The understanding Lacanian psychoanalysis makes of this game is that speech becomes the tool which soothes the cut.

Speech, however, speaks to and of. In its role as descriptor and indeed as communicator, it entertains, if you like, the play of relation or, in Hoen's terms above, 'the dialectic of distance and proximity' (2016, p. 105). The closer one comes to a sense that the word has arrived at its, what we might call 'perfect' description, then the more the subject is relieved of anxiety - even if only for a moment before its return. This relief occurs, in part, because the sanction of that perfection is achieved through the belief in it being the Other's sanction; the perfection of symbolisation is what Lacan calls 'knowledge' (2007, p. 14) and the sanction comes from discourses, science, religion and of course law. Importantly for our understandings later, there is no arrival of signification and indeed if there was, in Zizek's terms, this would be 'too much Real', even in the promise of its arrival the anxiety begins to emerge, as if desire will be eradicated, or again, in Salecl's terms, devoured.

The relief, then, is obtained in the play of proximity; the machinations, the industry and entertainment of its possibility. However, even this relief will never endure. Only death, in its role as universal signifier, can produce the perfect signification and, as this evocation makes clear, any proximity to death, again, produces anxiety rather than relieves it, thus the dialectic. What insists, for the subject, is the play with the object as a dialectic of relief and anxiety, and this is because there is always the insistence of the (im)perfect signifier, and the promise of what Lacan calls the object which has 'no specular image, in other words, no alterity' 
(2006, p. 693). This is the unrepresentable object - the objet petit a. As Lacan says of the game:

If it is true that the signifier is the first mark of the subject, how can we fail to recognize here - from the very fact that this game is accompanied by one of the first oppositions to appear - that it is in the object to which the opposition is applied in act, the reel, that we must designate the subject. To this object we will later give the name it bears in the Lacanian algebra - the petit a. (1977, p. 62)

The significance of this for law and for colonial Australia is the role of play, and what Lacan calls 'the radical vacillation of the subject' (p. 239) insofar as the game is precisely the effort to produce the subject, as such, through its toying with language and objects both inside and outside of itself. If we were to give this dynamic a Winnicottian reading we could understand that the object, like language itself - both in and out of control, like the child's blanket that is both in the mouth and outside it is an effort to, in Winnicott's terms, play with reality. ${ }^{5}$ Reality, loss, and lack of control are thus only manageable in their production of anxiety, through moments when the blanket can be held, sucked, and perform its role as entertainment.

Law, in its languages and, in Robert Cover's terms, its interpretations 'in the flesh' (Cover 1986, p. 1604), promises this form of management in its articulation of what is in and outside the self; or rather it promises, in Winnicott's definition, a mediation of 'the intermediate area between the subjective and that which is objectively perceived' (1971, p. 4). Law, in this sense, functions like religion and science in Lacanian terms that allow firstly for a group or mutual belief in the reality of the world, and then a modality for mediating their effects upon the subject. Where Lacan will call this belief 'reality' as a form of reducing the world of the subject to a

\footnotetext{
${ }^{5}$ Winnicott's title is Playing and Reality (1971), because he believes there is the objective world and the internal world, to say one plays with reality, is to give the dynamic a Lacanian inflection.
} 
perceptible experience 'where tension is maintained at its lowest level' through the death drive (2007, p. 16), Winnicott will describe religion, and indeed art, as an 'illusion' which transcends reality. As he says:

Studying the substance of illusion, that which is allowed to the infant and which in adult life is inherent in art and religion, and yet becomes the hallmark of madness when an adult puts too powerful a claim on the credulity of others, forcing them to acknowledge a sharing of illusion that is not their own. We can share a respect for an illusory experience, and if we wish we may collect together and form a group on the basis of the similarity of our illusory experiences. (1971, p. 4)

The very group that we might collect here is that of 'nation', however, as a collusion over mutual ideas and beliefs in what it consists of, where it begins and ends, what is its value and who are its members. ${ }^{6}$ And then one inflicts madness in its name, forcing others to share that 'illusion that is not their own'. What better description of colonisation in Australia and more broadly, ${ }^{7}$ and its subsequent policies of assimilation and acculturation?

\section{PART II - TWO NAMES FOR LAW, WHEN JURISDICTION CONTRADICTS}

Colonial jurisdictions always throw relief on the violences performed to inflict the madness, and it is in these jurisdictions that we see the fissures and foreclosures that indicate both the fragile nature of 'reality' and the aggressive work to produce it for all. That is, when jurisdiction contradicts, when law has two names and both mean 'here', then another effort comes into play to manage the anxiety. And it is in the aggression of such management, in the efforts to assert a mutual madness, as the

\footnotetext{
${ }^{6}$ The now well recited discussion of 'imagined communities' by Benedict Anderson (1983).

${ }^{7}$ See Patrick Wolfe (2014) for an excellent discussion of the similarities and differences in practices of colonization in Australia and the Americas.
} 
realities of law, that we can see the work of humiliation and its role in this management.

In Rush (2005) and Dorsett and McVeigh's (2002) descriptions of the legal situation in Australia, summed up as comments on the 1992 Mabo(2) judgment:

For the majority of the High Court, what remains unassimilable in and unassimilable to the body of the common law was the founding moment of settlement. (Rush 2005, p. 759 and in Dorsett and McVeigh 2002, p. 290)

Unassimilability of law here is articulated in the Mabo judgment of 1992, but the legacy of unassimilability insists. ${ }^{8}$ Not simply as the incapacity to claim moral authority as legitimate, but as the impossibility of, in psychoanalytic terms, reconciling distinct, and often contradictory fantasies attached to a symbolic world. Simply, law has two names in Australia (at least), and this not only evokes a practical problem of the authority to pronounce judgement, in cases such as Mabo, but it also suggests an entirely different trajectory of ontological authority, or authority over reality. In other circumstances in which this unassimilable relation to reality occurs it is resolved by the assertion of moral authority - simply 'their law is wrong' - as in the case of the allies' claim of legal authority in Nuremberg, which simply resorted to 'natural law' or 'the customary law and principles of civilised nations'. ${ }^{9}$ But Australia, not dissimilar to other colonial jurisdictions, has at once to acknowledge its own 'wrongness' as a violent colonial power that exercised common law over and above peoples who have their own systems of law - to acknowledge the breach of the

\footnotetext{
${ }^{8}$ Assimilation policies and practices also insist at the level of the actions of officials and the exercise of racist beliefs, see Cunneen (2007).

${ }^{9}$ As Douzinas says 'the tribunal re-discovered the main tenets of natural law: its insistence that a hierarchy of laws exists and that, irrespective of domestic law, universal legal principles prevail'
} (2009) 
'principles of civilised nations' by attempting the eradication of these systems - and to admit the presence (and continued presence) of these laws in the nation. We can understand this in this way: what we have, in Australia, are two clear registers of jurisdiction. Australian law which hovers over the many Indigenous nations in the land called Australia, and the nations themselves, which have their own system of laws which are, in many cases, contradictory in principle and practice to Australian law. $^{10}$

This hovering of Australian law has a history which allows us to begin to speak of the 'dialectic of distance and proximity' and the efforts to reconcile contradictory imaginations and the subsequent violences that were those efforts. That history begins a long time before invasion in 1788 but quickly (in western terms) progresses from the patches of jurisdiction that were 'asserted largely on the basis of a person's status, not on the basis of territory' (Dorsett and McVeigh 2012, p. 100) that were brought as common law from England to a jurisdictional claim of/as sovereignty which would cover the land called Australia. ${ }^{11}$ 'Australia' as a terrain of contradicting jurisdictions is not only historical but contemporary and insisting. There is now a documented understanding of the existence of Indigenous nations with their own governing structures and laws in Australia. ${ }^{12}$ As Patton notes:

With regard to the empirical claims made about Australian Aboriginal society, it is now accepted in

\footnotetext{
${ }^{10}$ Notably this contradiction has endured some attempts at resolution, which only exemplify some of the impossibilities of this, see ALRC (1986); Zdenkowski, (1994) often with devastating consequences. 11 'In Mabo (No. 2), Brennan $\mathrm{J}$ reminded us, again, that in a settled colony, such as Australia, the colonists bring with them "as much of the common law as is applicable to the circumstances of the colony"'. (Dorsett et al 2002, p. 293)

${ }^{12}$ See Black (2011), Watson (2014). There is also strong resistance to the legitimacy of the practices of these nations as law, however, see Cunneen (2007).
} 
both anthropology and law that they did possess systems of governance and customary law. (1996, p. 164)

While some of those societies have been injured, in many those systems remain extensive and in some cases have been further developed over the past 240 years. ${ }^{13}$ That these nations existed at the time of invasion in 1788 and then insisted through the subsequent years of colonisation is also clearly articulated in successive judgments that, at least in principle, overturn the 'hypothesis, there was no prior settled law in existence' (Patton 1996, p. 153). Specifically, the celebrated Mabo case in 1992 indicated what Brennan J called the 'fiction of terra nullius' (as the doctrine of empty land) but, as Patton has documented so clearly, there were several cases prior to this in Australia which had already acknowledged the 'fiction' as such (1996, 2000); even if the judgments did not then emerge favourably for those who endured this sentiment. The contortion around legitimacy of an Australian court to make a judgment over lands, which were illegally taken - that was the favourable judgment in Mabo - thus mapped the problem of jurisdiction that had insisted in prior judgments. The simple problem in these judgments was, and continues to be, one of authority. That is, how to even claim the authority to decide, to make a judgment, when the very claim upon which that authority is based is founded on the illegality of settlement, and thus of jurisdiction. $^{14}$

The cases of Murrell and Lowe in the $19^{\text {th }}$ century are where the registers begin to emerge as contradictions, but are quickly pasted over with an aggression

\footnotetext{
${ }^{13}$ The 'Congress of First Nations Peoples' in Australia is well established and is developing its own governing structures.

${ }^{14}$ As Patton notes 'if the high court accepts the prior existence of Aboriginal and Islander societies with their own laws and interests in land for the purpose of the common law, then it seems at best inconsistent, at worst hypocritical, to deny prior indigenous sovereignty'. (1996, p. 165).
} 
about who could speak for bodies and their behaviours on this land. Specifically, this aggression translated in Muldoon's terms, to 'the right over life and death'. ${ }^{15}$ And this was the coloniser's right exercised over Aborigines. The specific practice of killing Indigenous people with impunity was only challenged in 1827 with the case of $R \mathrm{v}$ Lowe (1827). Nathaniel Lowe, a military serviceman murdered “"Jackey Jackey” - a "native of the colony". In his defence, Lowe claimed that "Jackey Jackey" had himself committed a murder and sought to evade arrest. ${ }^{16}$ Lowe was found guilty, and then in 1836 the case of $R \mathrm{v}$ Murrell saw an Indigenous man Murrell found guilty of the murder of another Indigenous man, Jabingee (who was killed, by Murrell, as a practice of punishment under Indigenous law). In both cases the question was jurisdiction. In Murrell the defence argued assertively that Jabingee and Murrell were both subject to Indigenous laws of their 'clan' and that the British court had no jurisdiction. However, Forbes $\mathbf{J}$ in Murrell claimed definitively

This country was merely held by occupation, not by conquest, nor was it ceded; and where lands were so taken possession of, the King was bound to protect by his kingly power all parties living in it, or who came to visit it ... He, the Attorney General, stood there to protect the whites from the blacks, and the blacks from the whites; the colour made no difference to him. (Forbes 1836)

Thus there was an assumption of jurisdiction over the supposedly 'ceded' lands. As

${ }^{15}$ This was 'challenged and undercut on the frontiers of the colony. Both the Aborigines and the settlers, albeit for different reasons, continued to take life according to codes of justice that originated from customary sources’' (Muldoon 2008, pp. 61-62).

${ }^{16}$ As Muldoon further explains 'The plea hinged upon two distinct claims. In the first instance, counsel claimed that the Aborigine in question was not a person cognizable under British law. He could not be considered an "alien enemy" because no conquest had taken place, he could not be considered an "alien friend" because no alliance had ever been entered into and he could not be considered a British subject because no treaty, "either expressed or understood", had ever been concluded "between his country and that of the British King"' (2008, p. 63) 
Dorsett and McVeigh note, 'Murrell commenced the process of erasing any legal memory of a time in which the common law's jurisdiction was anything other than complete and unified' (2002, p. 296).

There are several things we can say about this erasure from a psychoanalytic perspective. Firstly, repression can be one form of erasure. In this case the repression functions, quite literally, as a repression of the fragmented nature of jurisdiction prior to the tying of law to land; a tying that became the definitive practice after Murrell. The judgment in Murrell attempted an eradication of any form of Indigenous legal legitimacy. At the same time, however, it also rendered the body of Jabingee the legal subject of the Crown, indeed the subject to be avenged through the force of the law. The mode of this avenging is through, firstly, the allocation of Murrell as 'murderer', but more crucially the claim as to the significance of the act, or in a Lacanian frame, the naming of the act in terms which will cohere an imaginative attachment to the symbolic world of British jurisdiction. As Muldoon notes of the tension inherent in the newly settled territories of New South Wales:

In this liminal space, the power of the sovereign to command obedience, as much from the settlers as from the Aborigines, rests upon its ability to gain a monopoly over the meaning of things. In declaring that the 'custom' of retribution will henceforth be known as a 'crime' of murder, in other words, Burton was staking a claim against rival powers that the right to define actions within the territory of New South Wales rested exclusively with the colonial sovereign. (Muldoon 2008, p. 69, my emphasis).

It is thus the 'right to define' that is at stake in Murrell (and indeed in any speech). The capacity to attach oneself to the symbolic world, through what Lacan calls 'passwords', ${ }^{17}$ is what is at stake in the management of anxiety for every subject.

\footnotetext{
${ }^{17}$ As Lacan says: Is it with these gifts, or with the passwords that give them their salutary nonmeaning, that language begins along with law? For these gifts are already symbols, in the sense that symbol means pact and they are first and foremost signifiers of the pact they constitute as the signified (2006,
} 
However in juris-diction, we have the promise of managing this anxiety by inflicting reality, in Cover's much reiterated terms, in 'the field of pain and death' (1986, p. $1601) .^{18}$

Let us pause for a moment to understand the effect of Murrell, or rather the assertion of meaning that was the effort at elision of alternative meaning and the crucial importance of this for anxiety in contemporary non-Indigenous Australians. If, in Dorsett and McVeigh's terms, the case of Murrell 'erased legal memory' of a time before any unified jurisdictional force in Australia it is because the language itself tied the symbol (murder) to a relation of bodies, to space (jurisdiction), to authority (judgment and sovereignty) and to each other (jurisdiction again). The significance of the reality of the act performed by Murrell was resignified in a manner which would, simply put, erase the possibility of another interpretation. Symbol (in this case 'murder') means 'pact' in Lacan's terms (2006, p. 225) and it is both a pact between subjects - an acceptance that that word refers to that thing - and, not mutually exclusively, it is a pact between the word and the thing itself. Fort, $d a$ (gone, here); the symbols gesture to an imagination of an event and an attempt to seal that imagination to the symbolic world that then becomes a possession of the child, that is both in and out of the child's mouth. In the game, fort da, the repetition makes the child's world so; in common law, in judgments, we might say something similar, but in Australia, with its fragmented and uncertain history, it is the tying of common law to the territory and specifically the bodies upon it - who experience that sentence in the flesh - that makes it so. This effect, in this liminal space - the frontier - where

\footnotetext{
p. 225).

${ }^{18}$ For Cover it is the pain and death of others that is the site of legal interpretation; for Lacanians it is to one's own death that speech speaks.
} 
meanings, imaginations and symbolic significance seem arbitrary (even meanings over life and death) the work of sovereign-certainty appears with aggression.

It is this rendering of an act as 'murder', which might have another name, and another significance under another law, ${ }^{19}$ that produces something of the anxiety insisting in the dual register of jurisdictions of Australia. It is the other name, a name unknown in non-indigenous law, undocumented in the writings or speech of the court, in the language of Murrell or Jabingee, that insists to undermine the capture of the event in speech. This impossibility is represented, I suggest, in the figure of Jabingee, allocated as murdered (and avenged through the punishment of Murrell), but present as the site of justice, and insisting in that undeconstructable way that Jacques Derrida describes as justice (1990). It is Jabingee who insists as the unrepresentable, or in Lacan's terms, non-specular quality of the law. Jabingee is the objet petit $a$, who is both to be captured in language and whose proximity and presence - underpinned by the knowledge of his own law - causes anxiety. As such, like the absent mother for whom only inadequate language comes to compensate, Jabingee must be managed.

\section{PART III - MURRELL IN THE 'SHADOWS'.}

Jabingee, having been allocated a status as 'perpetrator' under Indigenous law, is then redefined as 'victim' under British law; the executor of law Murrell is then named a 'murderer'. It is a simple equation in which the aggression of binaries appears in the 'liminal space' of the territories, with one name - murder - defining the authority and reality of positive law in Australia at that time. As if to highlight Cover's words on 'legal interpretation', judgment in 1836 enacts sovereign authority upon bodies,

\footnotetext{
${ }^{19}$ I have addressed the anxiety caused through the presence of an Other's law in relation to Sharia (law) in Rogers (2013).
} 
Indigenous bodies, as well as the body of Australian land, who then must comply with the subsequent years of judgments and the production of legal reality. But, there is a catch. Jabingee and Murrell, having been defined as such must remain as such - such is the fantasy of legal mastery over reality - and while legal interpretation takes place at a time, its repetition is required in order to ensure that pain and death are understood within the terms defined by legal authority, or else that authority loses its 'monopoly over the meaning of things' and thus its authority to name.

There are many locations in which this authority must be exercised in order to assert such a monopoly: judgments, of course, but also statute, the Australian Constitution and its subsequent interpretations, legal education, public policy and policing. It is in this last area that I will dwell for a moment on scenes of 'pain and death' in which Indigenous bodies are allocated names and the child's repetitive game re-emerges as an effort to quell the anxiety over jurisdiction in Australia. Indigenous bodies are ferociously subject to the management practices of law. Overpolicing of Indigenous people across all territories of Australia is well documented (see Cunneen 2006). The site that I focus on here is in inner city Sydney, the urban suburb known as Redfern, which has historically been an area where many Indigenous people have lived. ${ }^{20}$ In the last 15 years gentrification has forced many poorer Indigenous people out of this suburb, as the Indigenous Housing Council sold off this highly desirable real estate. But Redfern has a powerful reputation. As Katherine Biber notes, 'For decades associated with poverty, crime and Aborigines..."Redfern" is the terrifying

\footnotetext{
${ }^{20}$ Indigenous people constitute 2-3\% of the Australian population. The Northern Territory population is $60 \%$ Indigenous people, but most Indigenous people live in the urban centres of Sydney or Melbourne. Redfern in Sydney and Fitzroy in Melbourne have historically housed a disproportionate number of Indigenous people.
} 
zone of trouble and danger in the social imaginary of Sydney' (2002, p. 290). In the land of 'beauty and terror', ${ }^{21}$ Redfern, for non-Indigenous Australians, has historically been definitively experienced as the latter. As a suburb in which there has been a high population of Indigenous people, however, Redfern is also an area of land particularly several intersecting streets known as 'the block' - in which jurisdictions compete. And it is in this space that we see both the figures of Jabingee and Murrell emerge from the 'shadows', in former Prime Minister Paul Keating's terms, and it is here we see the efforts to assert the play of (over)policing that will defend against the anxieties of competing jurisdictions.

In 1992 Paul Keating made the famous 'Redfern Speech' about nonIndigenous responsibility for Indigenous people's marginalisation and disadvantage. The speech, however, offers more than an important assertion of responsibility, but gestures to the haunting figure of Indigenous people who return interminably to undermine non-Indigenous efforts at containment. As Keating says:

In Redfern it might be tempting to think that the reality Aboriginal Australians face is somehow contained here, and that the rest of us are insulated from it.

But of course, while all the dilemmas may exist here, they are far from contained....

perhaps the point of this Year of the World's Indigenous People: to bring the dispossessed out of the shadows, to recognise that they are part of us. (1992, my emphasis)

In a psychoanalytic reading this speech can be understood as a reference to the anxiety of proximity; that which will not be contained by law or language. That 'reality' is not 'contained' in these shadows suggests that there is something alive, something with its own life, that might break out of the place to which it has been consigned. In Redfern, as Keating notes, there is a temptation to believe that

\footnotetext{
${ }^{21}$ As described in Dorothy MacKellar's much cited poem on Australia 'My Country' (1908).
} 
Indigenous people are simply there, but what Keating points to is that non-Indigenous people are not 'insulated' and that what lurks in 'the shadows' is 'part of us [nonIndigenous Australia]'. 'Redfern' can be read as bringing back the legal memory that Murrell erased; it points to fragmentation of jurisdiction.

The reemergence of Indigenous jurisdiction could not be more obviously exemplified than in the 1992 celebrated and also infamous documentary Cop it Sweet. ${ }^{22}$ It is in this documentary that we see how policing Redfern is one example of where efforts at jurisdictional certainty insist as attempts to override anxiety. In previous work I have discussed the 'playful' techniques of humiliation that are applied by soldiers and guards at borders and checkpoints (2016). Redfern is itself a transitional space of jurisdiction, a kind of checkpoint in which the police are, in the words of the opening speech by a senior commissioner, 'expected' to ensure compliance. Techniques of humiliation are readily seen in Cop it Sweet as practices, which can be read as ensuring compliance, or certainly as components of surveillance and efforts to incorporate the subject into a relation of compliance.

Specifically the use of the 'unanswerable question' (Rogers 2016) is applied commonly as a technique which implicates the subject in the choice to be punished or not, as if there is such a choice. In one scene two police officers pull a car off the road and examine the car; seemingly without reason or cause. There are two young Indigenous men in the car, recognised by police before they stop the car. These men are then required to follow the officers around the car as they comment on the tires. The officers do not only comment, however; they also inquire of the driver: 'wouldn't like us to put it off the road and give it a defect sticker would ya? Would you like us to do that?'

\footnotetext{
${ }^{22}$ See Janet Chan's discussion of the multifarious reactions to this documentary (1995).
} 
It is a simple, seemingly benign interaction, but the young man is required to answer as to what he wants and does not want in respect of being punished. The question here forms more than a role of securing information about the tires, it also implicates the young man in the, supposed, choice to punish or not. 'Does he want to be punished? Does he?' This is similar to how torture techniques work to implicate the tortured subject in the 'choice' to experience pain, or not, thus ensuring that their own bodies become the weapon. ${ }^{23}$ It is also similar to how Lawrence Langer described the decisions of Jewish people during the Holocaust as the 'choiceless choice' (1980, p. 222). But here it specifically, I suggest, brings the young Indigenous man into the scene of jurisdiction as a figure imbued with the liveliness of the toy. That is, he is not subjugated entirely to the whims of the police officer; he is made to retain his own form of agency, his own form of life.

Unlike the common psychological understandings about exercising violence, the police here do not treat the young man as an object. He is part object and part subject, made to engage with them in a lively way - to answer as to what he wants and does not want - only to be told precisely what he will get, irrespective of his desire. It is in this sense that we can recognise the playfulness of the officer as not simply a resemblance to the cotton reel, that itself is thrown into 'the shadows' (under the bed) and then brought back at the whim of the child. The still-alive, uncontained object resembles more closely the 'transitional phenomena' that Winnicott interrogated in the child's world. The object, which Winnicott described commonly as a blanket or soft toy, functions specifically as a 'defense against anxiety' (1971, p. 5). This object is not only an inanimate toy, but is usually something soft; in fact it is required to be precisely so. The softness ensures that it has a life of its own, in its

\footnotetext{
${ }^{23}$ I have discussed this dynamic (2016) and its relation to Elaine Scarry’s work (1985).
} 
folds and falls. The shadows that appear in the folds, the way the soft fabric plays with light and succumbs to gravity means its slips from the hand, the mouth, the grasp of the infant. It is not quite controllable and, in its uncontrollable features, it is partly in and outside the jurisdiction of the infant. But importantly so. If it was entirely in control it would be of no use. It would be to manage nothing. In its liveliness, in its uncontainable properties and in its, in Lacan's terms, status as 'a small part of the subject that detaches itself from him while still remaining his, still retained' (1977, p.61), it functions as transitional; as what Winnicott calls 'the intermediate area between the subjective and that which is objectively perceived' $(1971$, p. 4) or, in Keating's terms, as still 'part of us'.

That there is something which is 'objectively perceived' is precisely what we will take issue with here in relation to the production of what Lacan calls 'knowledge' (2007, p. 14) or 'reality' through law, science or religion. However, Winnicott's belief that there are elements that might be perceived in such ways also offers us a way of understanding how anxiety functions: specifically to suggest that there is an outside of the body that is 'objective'. Law attempts to make reality so and, again, we can say that it is the presence of Indigenous people that undermines the objectivity of jurisdiction, or it undermines the universal relation between signifier and signified, between the signifying of the Real as 'reality'. As such, something must be managed. This is indeed why Lacan will say that the child repeats the game Fort Da. As he says: 'This signifies that the realization of the signifier will never be able to be careful enough in its memorization to succeed in designating the primacy of the significance as such' (1977, p. 61). That is, in between the throw and the word, or between the mouth and the voice, the anxiety insists.

We can see again how this space between the mouth and the voice is 
exemplified in Redfern in another scene from Cop it Sweet in which one man is arrested for 'offensive language'. The interaction begins in the shadows and is difficult to make out, but we hear the conversation:

David: Fucking shit.

Officer: what's your reason for swearing in the street like that...what's your reason?

D: I got no reason. I don't like your back up that's why...cause you're studying us, you're studying us, you're studying the block...

O: Yeah what's the problem?'

D: because I don't like you studying the block.

O: You don't like us what?

D: Studying.

O: Starting?

D: Studying. Studying.

O: Oh I see. Ok mate well you're under arrest for offensive language.

D: Oh bullshit. I have done nothing. I have done nothing. You're kidding I have done nothing...

O: You're under arrest for offensive language, now just hop in the back please.

D: you're kidding.

O: just hop in the back please....

David is taken to the police station. His belongings are removed. He is placed in a holding pen in front of the police desk for what are certainly several hours. He is finally charged with 'offensive language' and held overnight in a cell. We are told that he later appears before the magistrate and the charges are dismissed. The arrest of David and his subsequent experience at the station are peppered with scenes of other officers swearing at people in the street, and we have seen many such scenes across the span of the documentary. The point the filmmakers seem to be making is of 
inconsistency of police practice on the basis of racism. The opening comments from the same officer who makes the arrest that 'if you do something wrong you get treated the same as everyone else' is clearly undermined by the treatment of David. However, I suggest there is more at play in David's arrest than racist inconsistency, although David's 'race' is crucial. Something offended the officer in David's language. We can speculate that it was not simply his use of the words 'fucking shit'. I suggest it was more likely the subsequent comment on police 'studying' the block, which evoked the officer's seemingly disproportionate response.

In Winnicott's terms the blanket mediates objective reality, experienced as so alien and anxiety-provoking by the child. This mediation in Lacanian terms is performed by language, the word both in and outside the mouth. And it is the sound itself, 'voice', in Lacan's terms (2006, p. 693), discussed in depth by Mladen Dolar (2006), that falls from the cut, the orifice, that is the mouth in a non-specular way. Voice, that is, is one substance (if we can say substance), of the objet $a$. What is it, then, that appears in the voice of David that might cause him to be arrested? What is it that offended the police officer in his language? Recalling Hoen's configuration of the objet $a-$ it is 'the object of anxiety, which occurs when lack is lacking, or, put differently, when the subject gets too close to what causes its desire' (2016, p. 105) we can speculate that what causes the desire for non-Indigenous subjects, including the police, who affiliate with the laws of the land, is the proximity to what they might describe as justice, as a legitimacy of jurisdiction: that is, equality in policing ('you get treated the same as everybody else'), and in judgement ('He, the Attorney General, stood there to protect the whites from the blacks, and the blacks from the whites; the colour made no difference to him'). But remember there is a tension in this. While jurisdictional legitimacy is the goal, the impossibility of 'justice' for 
Indigenous people forms here the same role as the objet petit $a$; it is the object cause of desire and yet its proximity arouses anxiety. Thus justice must be entertained, engaged and held at bay all at once. When David names the impossibility of justice, when he so accurately points to the activity of the police 'studying the block' overpolicing in its most obvious activity - he brings the officer into proximity with his own (the officer's) image. But the proximity is intense, the desire for 'justice' potentially collapsing in the achievement of jurisdictional certainty.

The momentary proximity to justice, the production of the objet petit $a$ as specular, is to have it slip through one's fingers, delightfully, as an enhancement of the play. ${ }^{24}$ The officer in Cop it Sweet does something extraordinary that highlights the dynamic of engagement with what falls from the mouth of David. The officer, in the opening encounter with David, arrests him for offensive language. He removes David from the shadows and then places him in a containing pen (a thigh-high cage) in front of his desk for what appears to be several hours. He studies him. But it was precisely this dynamic that David named as the cause of his reason for swearing: 'I don't like you studying the block'. In placing David before him for several hours the officer is doubling the dynamic that is spoken of as the cause of the offensive language in the first place. David swears, he says, because he does not like being studied. The officer then holds him at arm's length looking at him, interrogating him, and taking his 'private property' to 'study'.

Officer: you got no Id in there at all? What's the other cards in there mate? Same thing? Or...

David: no, there isn't

\footnotetext{
${ }^{24}$ To produce oneself without desire equals death. In one sense the dynamic is similar to the relation with the snitch in the quidditch game in Harry Potter - the game is over, desire is over, once this elusive object is caught, but it is around this object that the entire game is organised.
} 
O: What's in the back there? How you go at TAB? Winner?

D: what this? (holds up card)

(O reaches into cage and takes cards)

D: eh, that's my private property

O: I know it is (looks at cards). Where do you live at? Where do you live?

D: I live on the block.

O: Beverly street? Louie street?

D: that's for you to find out.

David, in the holding pen before the officer, is gradually stripped of property, identity, his belt and finally shoelaces. But what remains in front of the officer is the figure resistant to being studied, assimilated or rendered inanimate before the law.

D: yeah, yeah. Shit. Jeez I hate cops. I'm gonna knock one of you out. Fair... What have I done wrong? That's what I want to know. What have done wrong?

O: you swore mate.

D: you expect me to hang myself in a cell? No way brother. I'm going to fight you all the way.

O: not a problem

D: I'm going to fight you all the way.

David's resistance is crucial, however, in the efforts to assert an illegitimate jurisdiction in the efforts to quell anxiety. He must be made to perform nonassimilation in order to be enjoyed as the animate object of/as justice. Like the blanket with its own living folds, the body before the officer is not inanimate; it is placed precisely in the relation that is most evocative of life. He is tormented, studied anew, perhaps in an effort to make him more lively.

As Lacan says of the loved one 'I love you, but, because inexplicably, I love in you something more than you - the objet petit a - I mutilate you' (1977, p. 263). 
Humiliation and mutilation, studying and torturing are partners in this production of the objet petit $a$, and in this equation Indigenous people are the required transitional phenomena. Remembering what Dorsett, McVeigh and later Rush point to as the unassimilable moment of settlement: violence. In the scene of David in a pen studied, questioned, stripped and finally placed in a cell - we have the effort to produce colonisation as the impossibility of justice. Knowing that all speech jurisdiction - in the ongoing colonial encounter called 'Australia', is a violence to the Indigenous people and laws, formerly and presently in practice, the Indigenous figure is made to perform the impossibility of justice. David points to the undeconstructable moment of justice, the officer then tries to hold the undeconstructable objet before him and have it perform in a mode that suggests proximity but not acquisition. Acquisition would be to render David inanimate, without life, what I have called elsewhere 'resurrection' (2017). Certainly there is an aggressive policy practice at work that tries to resurrect the 'Indigenous race' for the purposes of reliving the guilt of genocide, of colonisation, of decimation. But this is not the whole story. The Indigenous body must be made to perform in order to have the objet $a$ in proximity, not too close, but close enough - three feet from the desk in this case. This objet is both the cause of desire, in its potential achievement of unified jurisdiction, and it is the objet to be held at bay. Where Murrell was rendered significant as 'murderer', where Jabingee was rendered significant as victim, resurrected to perform the security of meaning, David is the objet petit $a$, but each action renders him specular and nonspecular at once. Finally, when David is crying, after hours in the pen, then he is taken to a cell. Tears, perhaps, being some substitute for voice. 
The Cop it Sweet documentary was made over 25 years ago. Things might have changed. Certainly Redfern has changed as gentrification pushes poorer Indigenous people to other parts of the city. However, the rates of incarceration of Indigenous people are higher; deaths in custody have increased with young Indigenous men being more likely to go to prison than to finish school. In 2004 TJ Hickey was chased by police and impaled on a fence; in 2016 Indigenous young people were shown to be humiliated and tortured at Don Dale youth detention centre in the Northern Territory. And anecdotal evidence of stop and search policing of Indigenous people indicates that little has changed. As I write, non-indigenous people are supposedly still not 'ready' to recognise Indigenous people in the Australian constitution, but recognition suggests that the issue might be settled.

Settling is not the point. The aggression of colonisation is an aggression that demands the final arrival of a violence that cannot arrive. Justice, in Derrida's terms, will always undermine that arrival, but justice in Australia is an exciting and terrifying prospect for non-Indigenous Australians all at once. It points to the possibility that law has two names; that imagination cannot ever be secured in the symbolic world of law; that there might be more than one or even two masters. This anxiety must be managed, but never eradicated. Indigenous people are both the disruption to this management and the objet $a$, which opens to its proximity. Humiliation is one form of management and enjoyment. It both keeps the subject alive and implicates it in the violence. It is not torture, it is not illegal; indeed it is the site of legality. As such, it is the product and promise of the collision of jurisdictions.

\section{REFERENCES}


Anderson, Benedict. 1983. Imagined communities: Reflections on the origin and spread of nationalism. London: Verso.

Australian Law Reform Commission (ALRC), 1986. The recognition of Aboriginal customary laws, Report No. 31: 3-17.

Biber, Katherine. 2002. The hooded bandit: Aboriginality, photography and criminality in Smith $v$ The Queen, Current Issues in Criminal Justice 3(3): 286-300.

Black, Christine. 2011. The land is the source of the law: A Dialogic encounter with Indigenous jurisprudence. London, UK: Routledge, Cavendish.

Brockie, Jenny. 1991. Cop it Sweet. ABC TV Documentaries, 66 mins.

Chan, Janet. 1995. Damage control: Media representation and responses to police deviance, Law Text Culture 2: 36-60.

Cover, Robert. 1986. Violence and the word. Yale Law Journal 95: 1601-1629.

Cunneen, Chris. 2006. Racism, discrimination and the over-representation of indigenous people in the criminal justice system: Some conceptual and explanatory issues, Current Issues in Criminal Justice 17(3): 329-346.

Cunneen, Chris. 2007. Assimilation and the re-invention of barbarism. Australian Indigenous Law Review (Special Edition) 11: 42-45.

Derrida, Jacques. 1990. Force of law: The 'mystical foundation of authority'. Cardozo Law Review 11: 921-1045.

Dolar, Mladen, 2006. Voice and nothing more. Cambridge, Massachusetts: MIT Press.

Dorsett, Shaunagh, and Shaun McVeigh. 2002. The law which governs Australia is Australian law, Law and Critique 13(3): 289-309.

Dorsett, Shaunagh, and Shaun McVeigh. 2012. Jurisdiction. London: Routledge. 
Douzinas, Costas. 2009. Are Rights Universal? The Guardian. https://www.theguardian.com/commentisfree/libertycentral/2009/mar/11/libert y-central-deconstructing-rights. Accessed on 26 May 2017.

Evans, Dylan. 1996. An introductory dictionary of Lacanian psychoanalysis. Hove and New York: Brunner Routledge.

Forbes C.J., Dowling and Burton JJ. 1836. $R$ v Murrell and Bummaree. Sydney Gazette, 19 and 23 February 1836.

Freud, Sigmund. 2001. Beyond the pleasure principle, group psychology and other works (1920-1922), trans. J. Strachey. London: Vintage.

Gaita, Rai. 2000. A common humanity: Thinking about love and truth and justice. London and New York: Routledge.

Hoens, Dominiek. 2016. Object $a$ and politics, Jacques Lacan: Psychoanalysis and politics, eds. S. Tomsic and A. Zevnik. London: Routledge.

Keating. Paul. 2000. The Redfern Park speech. In Essays on Australian reconciliation, ed. Michelle Grattan. Melbourne: Black Inc./Bookman Press, pp. 60-64.

Lacan, Jacques. 1977. Four fundamental concepts of psychoanalysis: Seminar XI, ed. Jacques-Alain Miller, trans. Alan Sheridan. London: Penguin.

Lacan, Jacques. 2006. Ecrits: The first complete edition in English. Trans. Bruce Fink. New York: W.W. Norton \& Company.

Lacan, Jacques. 2007. The other side of psychoanalysis: The seminar of Jacques Lacan, Book XVII. Trans. Russell Grigg. London: W.W. Norton \& Company. Langer, Lawrence. 1980. The dilemma of choice in the death camps, Centerpoint 4(Fall): 222-231.

Muldoon, Paul. 2003. Reconciliation and political legitimacy: The old Australia and 
the new South Africa. Australian Journal of Politics and History 49(2): 182196.

Muldoon, Paul. 2008. The sovereign exceptions: Colonization and the foundations of society, Social and Legal Studies 17(1): 59-74.

Patton, Paul. 1996. Sovereignty, law and difference: After the Mabo case. Alternatives, Global, Local, Political 21(2): 149-170.

Patton, Paul. 2000. The translation of indigenous land into property: The mere analogy of English jurisprudence..., Parallax 6(1): 25-38.

Rogers, Juliet. 2013. Law's cut on the body of human rights: Female circumcision, torture and sacred flesh. London: Routledge.

Rogers, Juliet. 2016. The work of humiliation - A psychoanalytic understanding of checkpoints, borders and the animation of the legal world. Law \& Critique 28(2): 215-233.

Rogers, Juliet. 2017. Is psychoanalysis universal? Politics desire and law in colonial contexts, Journal of Political Psychology, 38(4): 685-700.

Rowse, Tim. 1993. After Mabo: Interpreting indigenous traditions. Melbourne: Melbourne University Press.

Rush, Peter. 2005. Surviving common law: Silence and the violence internal to the legal sign, Cardozo Law Review 27(2): 753-766.

Salecl, Renata. 2004. On anxiety. London: Routledge.

Scarry, Elaine. 1985. Body in pain: The making and unmaking of the world. New York: Oxford.

Watson, Irene. 2014. Aboriginal peoples, colonialism and international law: Raw law. London: Routledge Glasshouse.

Winnicott, Donald. 1971. Playing and reality. London: Routledge. 
Wolfe, Patrick. 2014. Traces of history: Elementary structures of race. New York: Verso.

Zdenkowski, George. 1994. Customary punishment and pragmatism: Some unresolved dilemmas: The Queen v Wilson Jagamara Wilson, Aboriginal Law Bulletin 3(68): 26-27.

Zizek, Slavoj. 2006. The parallax view. Cambridge, Massachusetts: MIT Press.

\section{CASES:}

Mabo and Others $v$ Queensland (No.2) 1992, 175 CLR 1.

$R v$ Murrell and Bummaree [1836] New South Wales Supreme Court 35 (5 February 1836)

$R v$ Lowe, [1827] NSWKR 4; [1827] NSWSupC 32. 


\section{University Library}

\section{- M M I N E R VA A gateway to Melbourne's research publications}

Minerva Access is the Institutional Repository of The University of Melbourne

Author/s:

Rogers, JB

Title:

Humiliation, Justice and the Play of Anxiety in Competing Jurisdictions

Date:

2017-11-01

Citation:

Rogers, J. B. (2017). Humiliation, Justice and the Play of Anxiety in Competing Jurisdictions. LAW AND CRITIQUE, 28 (3), pp.289-305. https://doi.org/10.1007/s10978-017-9209-4.

Persistent Link:

http://hdl.handle.net/11343/282993 